\title{
Penegakan Kode Etik Kejaksaan terhadap Jaksa Yang Melakukan Tindak Pidana Narkotika
}

\author{
Nurhadisyah Mulqi Putri ${ }^{*}$, Puti Priyana ${ }^{2}$ \\ ${ }^{1,2}$ Fakultas Hukum, Universitas Singaperbangsa Karawang, Indonesia \\ Jalan HS Ronggowaluyo, Telukjambe Timur, Karawang, Jawabarat 41361 \\ Correspondence email: nurhadisyahmp@gmail.com, puti.priyana@fh.unsika.ac.id
}

\begin{abstract}
Abstrak. Sebagaimana dimaksud dalam Pasal 30 ayat 1 huruf b Undang-Undang tentang Kejaksaan, Jaksa Penuntut Umum sebagai penyidik publik berwenang untuk mendakwa kasus-kasus demonstrasi kriminal. Untuk situasi ini, khususnya opiat pelanggaran sebagaimana diatur dalam UU Narkotika dan tidak dapat dipisahkan dari kerangka keadilan pidana. Tugas kejaksaan dalam mengusut penjahat opium adalah memfasilitasi dengan anggota polisi lainnya, khususnya pejabat BNN, Polri, dan PPNS. Kajian ini menggunakan metodologi yuridis regularisasi, dengan melihat dan menguraikan isu-isu hipotetis mengenai standar, asal usul, sila dan standar legitimasi yang sesuai dengan persyaratan hukum terhadap penyidik yang melakukan pelanggaran opiat. Hasil penelitian menunjukkan bahwa UU Narkotika tidak mengatur ruang pemeriksa dalam kasus opiat; mereka hanya mengesahkan awal ujian dan mendapatkan berita acara ujian. Penghalang yang paling dominan adalah mengetahui kenyataan yang ada di lapangan mengingat Jaksa Penuntut Umum tidak bisa mengusut kasus opiat di lapangan. kasus penyalahgunaan opiat karena opiat diidentikkan dengan kepentingan umum. Undang-undang tentang opiat seharusnya memberikan posisi kepada pemeriksa untuk menjadi agen.
\end{abstract}

Kata Kunci: sanksi, kode etik jaksa, narkotika.

Abstract. As indicated by Article 30 passage 1 letter b of the Prosecutor's Law, the Public Prosecutor as a public investigator has the power to indict instances of criminal demonstrations. For this situation, particularly opiates wrongdoings as managed in the Law on Narcotics and can't be isolated from the criminal equity framework. The job of the investigator's office in arraigning opiates crooks is to facilitate with other policemen, particularly BNN officials, the Police, and PPNS. This review utilizes a regularizing juridical methodology, by looking at and deciphering hypothetical issue concerning the standards, originations, precepts and legitimate standards identifying with law requirement against investigators who carry out opiates violations. The outcomes show that the Narcotics Law doesn't manage the examiner's office in opiates cases; they just endorse the beginning of the examination and get the minutes of the examination. The most prevailing deterrent is knowing current realities on the ground considering the way that the Public Prosecutor can't explore opiates cases in the field. opiates wrongdoing cases since opiates are identified with the public interest. The law on opiates should give the examiner the position to become agents.

Keywords: sanction, prosecutor code of ethics, narcotic.

\section{PENDAHULUAN}

Dalam pandangan Pancasila dan UUD 1945, pelaksanaan aturan dan pemerataan adalah suatu prasyarat utama untuk mencapai suatu tujuan umum. ${ }^{1}$ Salah satu andalan Pemerintah dalam kapasitasnya untuk mengakui tujuan umum adalah Kejaksaan Republik Indonesia yang ditugaskan, kapasitas, dan kewenangan sebagai Penuntut Umum. Undang-Undang Nomor 16 Tahun 2004 tentang Kejaksaan Republik Indonesia (disingkat UU Kejaksaan) dideklarasikan pada tanggal 26 Juli 2004 untuk semakin matang kedudukan dan tugas Kejaksaan Republik Indonesia sebagai suatu instansi Pemerintah yang melakukan kegiatan kekuasaan negara di bidang penuntutan.

Kejaksaan sebagai organisasi pelaksana hukum menjalankan kewajibannya secara bebas dengan menjaga kebebasan dasar dalam suatu negara mapan yang berpedoman pada Pancasila dan Undang-Undang Dasar Negara Republik Indonesia Tahun 1945 dan secara tegas diatur dalam Undang-Undang Nomor 16 Tahun 2004 tentang Kejaksaan Republik Indonesia. Sebagai lembaga administrasi yang melengkapi kekuasaan negara dalam bidang penuntutan dan tugas-tugas yang berbeda tergantung pada pedoman hukum, Kejaksaan memerlukan adanya suatu tatanan pemikiran, aturan implisit dan tata cara kerja bagi Kejaksaan dengan mengingat standar yang ketat, kualitas yang mendalam, kebaikan. dan berfokus pada perasaan kesetaraan dan kualitas-kualitas manusia dalam masyarakat. Dalam melaksanakan kewajiban dan keahliannya, seorang penguji dituntut sebagai tenaga ahli yang sah, memiliki karakter amanah, disiplin, sikap kerja keras yang tinggi dan sarat dengan tanggung jawab, konsisten menyadari diri dengan memahami pergantian peristiwa yang mendunia, tanggap dan siap menyesuaikan diri. untuk menyimpan gambar ahli dan eksekusi. penyelidik dan tidak buruk secara intelektual. ${ }^{2}$ Pemeriksa sebagai otoritas terbuka secara

${ }^{1}$ Supriadi, Etika \& Tanggung Jawab Profesi Hukum di Indonesia, (Jakarta: Sinar Grafika, 2006), hal. 128

${ }^{2}$ Liliana Tedjosaputro, dalam Supriadi tentang Etika \& Tanggung Jawab Profesi Hukum Di Indonesia,Sinar Grafika, Jakarta, 2006, hlm. 132 
konsisten menunjukkan pengabdiannya untuk melayani masyarakat pada umumnya dengan berfokus pada kepentingan umum, tunduk pada janji jabatan, mempertahankan prinsip Tri Krama Adhyaksa, dan mendorong asosiasi yang menyenangkan dengan otoritas publik lainnya. Penguji sebagai individu dari daerah secara konsisten menunjukkan model asli, bertindak dan bertindak sesuai hidup dan menciptakan nilai-nilai dan pedoman hukum.

Secara normatif (das sollen) kewajiban dan komitmen jabatan pemeriksa dapat dianggap besar, meliputi jangkauan yang luas dan serius. Pemeriksa atau khususnya penyidik memiliki kedudukan sebagai agen Negara di bidang pemerataan. Eksekutif hukum di Indonesia akan menjadi yang terbaik di kelasnya dan hebat jika kewajiban dan komitmen jabatan pemeriksa dilakukan dengan baik, dengan tetap menjaga optimisme organisasi penyidik sebagai penguasa pemerataan meskipun kenyataannya demikian. dihadapkan pada faktor-faktor kehidupan yang sebenarnya. Mafia hukum, itulah istilah yang saat ini marak ditelaah secara lokal. Bagaimana tidak, kejaksaan yang seharusnya menjalankan hukum justru memanfaatkan hukum sebagai kawasan bisnis. Kualitas terhormat hukum tidak lagi dipertahankan. Dalam menangani suatu perkara di pengadilan, tidaklah fenomenal bagi petugas kepolisian, karena situasi ini hakim, penyidik, dan penasehat hukum "menjadi bahan olok-olok". Bahkan hukum dimainkan untuk keuntungan mereka sendiri. ${ }^{3}$

Yang dimaksud dengan penyidik adalah kekuasaan praktis yang disahkan oleh undang-undang berperan sebagai pemeriksa umum dan melaksanakan pilihan pengadilan yang telah memperoleh kekuatan hukum yang super tahan lama dan kekuatan-kekuatan lain yang bergantung pada undang-undang. ${ }^{4}$ Situasi utilitarian penyidik adalah suatu tempat yang bersifat khusus dalam pergaulan pemeriksa yang karena kemampuannya memungkinkan kelancaran pelaksanaan kewajiban pemeriksa. Penyidik ditunjuk dan diberhentikan oleh Jaksa Agung yang merupakan perintis dan orang yang paling ditinggikan yang bertanggung jawab atas Kejaksaan yang digerakkan, mengendalikan pelaksanaan kewajiban dan tenaga ahli Kejaksaan.

Yang dimaksud dengan Jaksa Agung adalah pejabat negara yang dipilih dan disudahi masa jabatannya oleh Presiden dengan syarat-syarat yang sudah diatur dalam undang-undang. Sejak Jaksa Agung ditunjuk oleh Presiden, maka dalam melaksanakan kewajibannya Jaksa Agung melakukan kewajiban negara, mengingat Presiden memilih Jaksa Agung bukan sebagai kepala negara melainkan berkedudukan sebagai kepala negara (kekuatan federatif). Apalagi pemeriksa yang dipilih oleh Jaksa Agung dalam melakukan kewajibannya adalah menyelesaikan kewajiban negara dan bukan kewajiban pemerintah. Pemeriksa dalam melaksanakan kewajiban dan kapasitasnya harus senantiasa berpedoman pada kode etik moral, yang merupakan Peraturan Jaksa Agung Republik Indonesia Nomor: PER-067/A/JA/07/2007 tentang Tata Tertib Etika Kejaksaan. Dilihat dari gambaran yayasan tersebut, maka perincian permasalahan yang muncul dalam tinjauan ini merupakan pertama bagaimana pengelolaan kode etik bagi pemeriksa di Indonesia, kemudian cara menentukan kasus pelanggar ketentuan Kode Etik Kejaksaan. yang melingkari opiat.

\section{METODE}

Untuk memimpin eksplorasi, strategi menjadi sesuatu yang langsung menemukan jawaban atas masalah yang disajikan dalam ujian. Mengingat hal ini, strategi pemeriksaan dalam ulasan ini adalah sebagai berikut :

1. Metode Pendekatan

Metodologi yang digunakan adalah pengaturan yuridis. Metodologi tersebut dilengkapi dengan melihat dan menguraikan masalah hipotesis mengenai standar, asal usul, prinsip dan standar yang sah yang mengidentifikasi dengan implementasi hukum terhadap penyidik yang melakukan pelanggaran opiat.

2. Spesifikasi Penelitian

Metodologi yang digunakan adalah standarisasi yuridis. Metodologi dilakukan dengan mengkaji dan menguraikan masalah hipotesis mengenai standar, asal usul, prinsip dan standar yang sah yang diidentifikasi dengan otorisasi hukum terhadap pemeriksa yang melakukan pelanggaran opiat.

3. Bahan Data dan Alat Utama

Materi sah yang dipertimbangkan dan diselidiki dalam ulasan ini menggunakan informasi opsional, meliputi:

a. Bahan Hukum Primer

Bahan hukum esensial adalah bahan hukum yang mempersempit atau menyebabkan individu tunduk pada hukum, misalnya pedoman hukum dan pilihan hakim. Materi sah penting yang digunakan pencipta dalam karya ilmiah ini.

b. Bahan Hukum Sekunder

Bahan pembantu yang sah sebagian besar sebagai penilaian/ajaran/spekulasi yang didapat dari tulisan halal, hasil penelitian, artikel logis, dan situs yang diidentifikasi dengan penelitian. Bahan tambahan yang sah pada dasarnya digunakan untuk memberikan klarifikasi tentang bahan-bahan penting yang sah. Dengan materi tambahan yang halal, analis akan dibantu untuk memahami/ menyelidiki materi penting.

\footnotetext{
${ }^{3}$ Sukarton Marmosudjono, Melihat Nilai Etika dari segi Keluhuran Hukum, jakarta, 1998

${ }^{4}$ Soerjono Soekanto, tentang pengertian Jaksa,Jaksa Agung, Jakarta, 2009,hlm. 12
} 


\section{c. Bahan Hukum Tersier}

Bahan sah tersier adalah bahan hukum yang membantu bahan hukum dasar dan memilih bahan hukum dengan memberikan pengaturan dan pemahaman bahan hukum lainnya. Bahan halal yang digunakan oleh pembuatnya adalah Kamus Besar Bahasa Indonesia dan Kamus Hukum. Juga, alat pengumpulan informasi adalah melalui studi menulis, khususnya penyelidikan dokumentasi undang-undang dan artikel yang diidentifikasi dengan eksplorasi ini.

4. Teknik Pengumpulan Data

Tata cara penilaian dan pengumpulan ketiga bahan hukum tersebut menggunakan laporan naratif. Pemeriksaan naratif difokuskan pada pemeriksaan arsip yang berbeda, baik yang berkaitan dengan undang-undang dan pedoman maupun laporan yang ada.

5. Analisis Data

Pemeriksaan khusus yang digunakan adalah teknik pemeriksaan pengaturan subyektif. Teknik pengaturan subyektif ini bergantung pada bahan legitimasi esensial sebagai hukum tertentu, kemudian pada saat itu dirinci secara subyektif, khususnya penyelidikan yuridis.

\section{HASIL DAN PEMBAHASAN \\ Kode Etik Profesi Jaksa di Indonesia}

Kata moral, yang sering disinggung sebagai moral, atau morals (bahasa Inggris), mengandung banyak implikasi. Sejauh latar belakang sejarah (awal kata), istilah moral berasal dari kata latin "ethicus" dan dalam bahasa Yunani diklasifikasikan "ethicos" yang berarti kecenderungan. Akibatnya, seperti yang ditunjukkan oleh kepentingan pertama, apa yang seharusnya diterima adalah jika itu sesuai dengan kecenderungan individu. Kemudian, pada saat itu sedikit demi sedikit pengaturan ini berubah, bahwa akhlak adalah ilmu yang mengkaji tentang persoalan perbuatan atau tingkah laku manusia, yang dapat diambil keputusan tentang yang baik dan yang dapat dinilai buruk. ${ }^{5}$

Situasi praktis pemeriksa adalah dalam gagasan tentang kemampuan khusus yang melakukan dakwaan. Bahwa untuk menjadikan seorang pemeriksa yang memiliki kejujuran individu dan disiplin yang tinggi untuk melakukan kewajiban kewenangan hukum dalam mengakui keadilan dan kebenaran, penting untuk memiliki kode etik ahli bagi penyidik. Kode etik pemanggilan pemeriksa diatur dalam Pedoman Jaksa Agung Republik Indonesia Nomor: PER067/A/JA/07/2007 tentang Kode Etik Penuntut Umum. Pada tataran mendasar, dalam melaksanakan kewajiban cakap, penyidik berkewajiban :

1. Mematuhi hukum, pedoman hukum, dan pedoman resmi terkait.

2. Perhatikan aturan cepat, mudah, biaya minimal sesuai metodologi pengaturan.

3. Mengingat keyakinan dan bukti yang sah untuk mencapai keadilan dan kebenaran.

4. Bersikap otonom, terbebas dari dampak langsung atau menyimpang, faktor tekanan atau bahaya penilaian populer.

5. Bertindak secara adil dan merata.

6. Menerangi atau berpotensi memberikan keistimewaan bagi tersangka atau terdakwa atau orang yang bersangkutan.

7. Terlebih lagi sebagaimana tertuang dalam Pasal 3 Peraturan Jaksa Agung Republik Indonesia Nomor: PER067/A/JA/07/2007 tentang Kode Etik Kejaksaan.

Sehingga dalam memahami suatu bantuan publik yang luar biasa, seorang pegawai pemerintah harus mentaati semua kode etik pegawai negeri yang telah dikelola sebagai kewajiban pegawai negeri. Sebagai bentuk apresiasi dari otoritas publik atas pameran para pegawai pemerintah ini, ada reward. Sementara itu, jika ada pegawai negeri yang menyalahgunakan pedoman yang telah dibuat, akan dikenakan sanksi (sanksi). Kode moral adalah jenis standar yang disusun yang dibuat secara efisien tergantung pada standar moral yang ada dan bila diperlukan dapat berfungsi sebagai instrumen untuk memberikan penilaian pada berbagai kegiatan yang secara sah objektif (kehadiran pikiran) dianggap menyimpang dari kode moral. Dengan demikian kode etik merupakan kesan terhadap apa yang tergolong "ketenangan", karena segala sesuatu dibuat dan diterapkan dari dan untuk melayani perkumpulan orang (panggilan) itu sendiri.

Kode etik panggilan adalah ikrar jabatan yang juga dipertegas oleh otoritas negara. Kode moral dan ikrar merupakan jaminan yang harus dipegang teguh. Artinya, tidak ada kapasitas untuk menanggung setiap individu yang menyalahgunakannya. Hal ini sah, ada persyaratan untuk persetujuan brutal terhadap pelanggar ikrar dan ahli kode etik. Memang, jika memenuhi unsur pidana atau kegiatan umum, pelanggar ikrar dan kode etik harus dibawa ke pengadilan. Kita juga harus adil dan spesifik dalam melakukan penegakkan hukum di Indonesia. Kode moral dan janji jabatan harus benar-benar ditegakkan. Panggilan apa saja sebenarnya tidak mempunyai sifat kebal di bidang hukum. Penganiayaan terhadap panggilan dengan berlindung di balik kode etik ahli harus dimusnahkan. Kita harus menghentikan tindakan palsu dan manipulatif dari elit tertentu di mata publik. Hal ini penting dilakukan, dengan

${ }^{5}$ Harian Orbith,Pengertian Etika dalam artian luas , Jakarta, 2009,hlm. 32 
asumsi Indonesia perlu menjadi bangsa dan negara yang terhormat. ${ }^{6}$ Kode Akhlak Ahli merupakan cara untuk membantu pelaksana sebagai ahli agar tidak merusak akhlak yang cakap. Ada tiga perhatian utama yang merupakan komponen dari kode ahli moral:

1. Kode etik ahli memberikan aturan kepada setiap individu dari panggilan sehubungan dengan standar keterampilan yang dapat dibuktikan yang ditetapkan. Ini menyiratkan bahwa dengan kode moral yang ahli, pelaksana yang mahir dapat menyadari apa yang seharusnya mungkin dan apa yang tidak mungkin.

2. Kode etik ahli adalah suatu cara pengendalian sosial bagi daerah atas pemanggilan yang bersangkutan.

Kode etik ahli menjaga halangan dari pihak di luar asosiasi ahli sehubungan dengan hubungan moral dalam partisipasi cakap. Signifikansi ini dapat diklasifikasi bahwa spesialis yang mahir di kantor atau organisasi lain tidak boleh mencampuri pelaksanaan panggilan di kantor atau organisasi yang berbeda.

Penyidik memiliki komitmen yang harus diselesaikan sesuai pengaturan di atas, dalam melakukan kewajiban cakap, Penuntut dilarang: ${ }^{7}$

1. Memanfaatkan posisi atau potensi kekuasaannya untuk kepentingan individu dan juga kelompok lain.

2. Mengendalikan realitas yang sah dalam menangani kasus. Dalam memutuskan premis yang sah untuk dipaksakan pada tersangka atau yang berperkara selama waktu yang dihabiskan untuk menangani suatu kasus, wajib sesuai dengan kenyataan hukum yang berlaku dan tidak boleh memutar balikkan kenyataan yang mengakibatkan lemah atau meniadakan pengaturan pidana yang seharusnya dibebankan dan didemonstrasikan.

3. Memanfaatkan kemampuan dan posisi mereka untuk menjatuhkan mereka secara aktual atau potensial secara mental. Pembatasan mencekik melalui melemahkan/mengejutkan untuk memperoleh tambahan individu atau kelompok lain.

4. Menyebutkan serta mendapatkan hadiah atau potensi keuntungan dan melarang keluarga mereka untuk menyebutkan dan tambahan mendapatkan hadiah atau potensi keuntungan mengenai jabatannya. Usaha untuk meminta dan mendapatkan tambahan meskipun tidak ada perkembangan melalui pemberian atau hadiah merupakan pelanggaran sebagaimana dimaksud dalam bagian ini. Penolakan untuk meminta atau berpotensi mendapatkan hadiah dan manfaat tambahan, termasuk untuk keluarga, ke atau dari pertemuan tertentu direncanakan untuk menghindari tujuan tertentu dengan tujuan dapat mempengaruhi penyidik dalam melakukan kewajiban ahlinya. Selain itu, juga direncanakan untuk menjaga kejujuran penyidik.

5. Terlebih lagi sebagaimana tertuang dalam Pasal 4 Peraturan Jaksa Agung Republik Indonesia Nomor: PER067/A/JA/07/2007 tentang Kode Etik Kejaksaan.

Pemeriksa sering dirusak oleh keterangan dari berbagai pertemuan di berbagai media yang tidak berimbang, salah atau sakit dalam data, dan pada umumnya akan merugikan penyidik, pemeriksa sesuai keadaan yang sebenarnya dapat memberikan data yang terbatas pada kasus-kasus khusus yang diperiksa di pengadilan. tahap pendahuluan di pengadilan agar ada penyesuaian data yang diperoleh masyarakat pada umumnya. Data yang diberikan tidak dibenarkan termasuk data yang bisa membuat kerugian dalam menangani kasus. Juga, data tidak boleh mencakup kasus-kasus berbeda yang tidak berkaitan dengan kasus yang sedang ditangani. ${ }^{8}$

\section{Penyelesaian Kasus Pelanggaran Kode Etik Jaksa Kronologi Perkara yang melibatkan Jaksa}

Umriani, seorang pemeriksa di Sumatera Utara, terancam diberhentikan dengan alasan terkait menjadi perwakilan kasus dalam kasus shabu-shabu opiat. Hal itu diungkapkan Jaksa Agung Muda Pengawasan (Jamwas) Marwan Effendi. "Kalau terbukti, disiplinnya akan ekstrim," kata Marwan kepada wartawan, Kamis (19/8).

Pemberitaan tentang penyidik Umriani umumnya dilingkari di beberapa media. Penjelasannya, Kepala Kejaksaan Tinggi (Kejati) Sumut mengusulkan pengusiran pemeriksa Umriani ke Kejaksaan Agung. Lebih lanjut Marwan menjelaskan, pihaknya belum mendapatkan dampak dari penilaian pemeriksa Umriani yang dilakukan oleh manajemen Kejaksaan Agung Sumut. Marwan, yang merupakan mantan anggota Jampidsus, mengklarifikasi bahwa bentuk disiplin berat yang bisa dikenakan kepada penyidik Umriani adalah pembebasan tercela atau dalam hal apapun dengan hormat. Juga, keluar dari posisi yang berguna atau yang mendasarinya. "Saya sebenarnya menunggu laporan dari Kepala Staf Sumut. Penurunan peringkat bergantung pada tingkat kesalahan yang ditunjukkan nanti," katanya.

Secara mandiri, pimpinan Pusat Penerangan Hukum (Kapuspenkum) Kejaksaan Agung, Babul Khoir Harahap, menggarisbawahi bahwa penyidik Umriani sudah cukup lama tidak diberi komando menangani kasus. Oleh karena itu, pemeriksa Umriani memiliki opsi untuk 'bermain' dengan kasus yang sedang ditanganinya. Petinggi Kejaksaan Tinggi

\footnotetext{
${ }^{6}$ M. Yahya Harahap, Kode Etik sebagai pelaksana para profesionaletika profesi,Jakarta, 1998

${ }^{7}$ Dr. Sidharta, SH.,MH., Moralitas PROFESI HUKUM, Bandung : PT Refika Aditama, 2006.

${ }^{8}$ Agus Santoso, 2014. Hukum, Moral, Dan Keadilan. Yang Menerbitkan Kencana Prenada Media Group : Jakarta
} 
(Kejati) Sumut sebelumnya menjelaskan, pemeriksa Umriani saat ini berstatus utilitarian dalam pandangan Kejaksaan Sumut. "Dia kadang-kadang diberi kasus, karena kita resah," katanya. Perlu diketahui, kegiatan penyidik Umriani terbongkar di kalangan kelompok Angling Yusuf, termohon dalam kasus pengobatan karena tidak mendapatkan kepastian putusan. Keluarga Calculating mengakui bahwa mereka telah memberikan Rp. 318 juta kepada pemeriksa Umriani dengan imbalan hukuman di bawah 10 tahun. Bagaimanapun, pengadilan terdekat memiliki pandangan alternatif. Dengan demikian, putusan pengadilan terhadap Angling bahkan 10 tahun penjara. Memang, tidak mentolerir pilihan tersebut, keluarga Angling meminta uang kembalian yang telah diberikan kepada penyidik Umriani. Bagaimanapun, uang yang dikembalikan hanya Rp. 150 juta. Sementara itu, kelebihan Rp. 168 juta tidak didapatkan oleh keluarga Angling. Pada tahun 2011, Jaksa Umriani dikeluarkan dari posisinya oleh kepala petugas hukum. Penyidik Umriani terbukti menjadi spesialis dalam badan obat bukti terhadap keluarga Angling Yusuf. Dengan pilihan tersebut, jelasnya, JPU saat ini tidak bisa mengikuti sidang dan sidang dakwaan.

\section{Analisis Kasus yang melibatkan Jaksa}

Kode etik cakap adalah standar yang ditetapkan dan diakui oleh perkumpulan ahli, yang memandu atau menawarkan pedoman kepada individunya bagaimana mereka harus bertindak dan sekaligus memastikan sifat etis dari panggilan sesuai dengan wilayah setempat. Selain itu, satu orang dari majelis ahli menyimpang dari kode etik, maka pada saat itu majelis ahli akan dikotori menurut masyarakat umum. Oleh karena itu, pertemuan ahli harus menyelesaikannya tergantung pada kekuatannya sendiri. ${ }^{9}$ Untuk ahli kode etik penyidik di Indonesia telah diatur dalam Peraturan Jaksa Agung Republik Indonesia Nomor: PER 067/A/JA/07/2007 tentang Kode Etik Pemeriksa. Dimana dalam Pasal 4, dalam menyelesaikan kewajiban cakap, Penuntut Umum dilarang untuk :

1. Memanfaatkan posisi mereka dan juga kekuatan untuk kepentingan individu atau kelompok lain yang berpotensi;

2. Mengontrol realitas hukum dalam penanganan kasus;

3. Memanfaatkan kemampuan dan kekuatan mereka untuk turun secara aktual atau potensial secara mental;

4. Menyebutkan dan tambahan mendapatkan hadiah serta keuntungan dan menghalangi keluarga mereka untuk menyebutkan atau berpotensi mendapatkan hadiah serta keuntungan mengenai posisi mereka;

5. Menangani kasus-kasus yang memiliki kepentingan individu atau keluarga, memiliki hubungan bisnis, pesta atau moneter atau memiliki nilai keuangan langsung atau tidak langsung;

6. Bertindak merugikan dalam struktur apapun;

7. Menyusun penilaian umum yang dapat merugikan kepentingan hukum;

8. Memberikan data kepada publik kecuali jika terbatas pada masalah khusus dari kasus yang sedang ditangani.

Atas perbuatan JPU Uraini terbukti tidak mengindahkan kode etik penyidik pasal 1 dan 4, dimana JPU Uraini mendapat uang tunai dari keluarga Angling Yusuf sebesar Rp. 318 juta dengan kompensasi yang sah oleh Angling di bawah 10 tahun penjara. Namun dalam eksekusinya, Angling divonis 10 tahun penjara dan uang yang dikembalikan hanya Rp. 150 juta. Ini menunjukkan bahwa Jaksa Uraini menerima suap dan menangani situasinya untuk peningkatan individu. Indikasi kegiatan ahli yang mengabaikan kode etik ahli karena alasan yang paling esensial mutlak, baik sebagai individu individu dari daerah setempat maupun dalam kaitannya dengan hubungan kerja dalam perkumpulan, pemanggilan. Sebagaimana dikemukakan oleh Abdulkadir Muhammad, ada beberapa alasan yang menyebabkan seruan yang sah mengabaikan kode etik ahlinya, antara lain : ${ }^{10}$

1. Pengaruh Posisi, Seseorang mengabaikan kode etik ahlinya karena dia merasa terpaksa jika dia adalah bawahan dan perlu untuk memperhatikan dan tunduk pada setiap permintaan yang dibuat oleh atasannya.

2. Dampak industrialisme, pengabaian kode etik panggilannya karena meningkatnya kebutuhan yang mana tidak dapat ditutupi hanya dengan gaji yang didapatkan. Hal ini mendorong seseorang untuk mendapatkan gaji yang lebih besar melalui jalur yang mudah, khususnya dengan mencari pembayaran untuk administrasi dari perkumpulan yang dilayaninya.

3. Dampak Lemahnya Iman, Seseorang mengabaikan kode etik panggilannya karena tidak memiliki benteng kokoh dari pelajaran yang ketat. Sehingga menyebabkan terpikat dan terpikat oleh berbagai jenis material di sekitarnya.

Oleh karena itu, harus ada jawaban yang bisa menangani masalah kode etik ahli, termasuk kode etik penyidik. Pengaturan-pengaturan yang dapat dihadirkan untuk membuat pelaksanaan yang layak dari kode etik panggilan yang sah antara lain:

1. Mengenai, harus ada kerangka kemajuan yang bergantung pada kerangka legitimasi. Ini menyiratkan bahwa kemajuan posisi untuk penyelidik luar biasa dan sejarah besar. Tidak didasarkan pada penghargaan yang diberikan

\footnotetext{
${ }^{9}$ Muhammad Abdulkadir, Ada beberapa pengaruh dalam kode etik profesinya,Semarang, 2007. 28

${ }^{10}$ Muhammad Abdulkadir, Ibid.,hlm28
} 
kepada atasan atau divisi pelatihan dan kepegawaian yang telah berubah menjadi informasi longgar yang telah menjadi praktik khas di kantor penguji.

2. Diidentikkan dengan komersialisasi, penting untuk menerapkan social assent kepada pelanggar kode etik ahli dari pemeriksa, sehingga dapat memberikan dampak hambatan dan mencegah pelaku lainnya yang diharapkan untuk mengajukan pelanggaran. Ijazah sosial, misalnya, pelakunya dihukum kerja sosial, membersihkan jalan dengan memakai pakaian yang menyalahgunakan kode etik ahli dan diawasi oleh orang-orang pada umumnya di kota.

3. Diidentifikasi dengan kepercayaan diri yang tidak berdaya, penting untuk menerapkan sekolah ketat yang hebat. salah satu item yang masuk akal bagi pelanggar kode moral adalah dikirim dari sekolah-sekolah Islam untuk nonMuslim, dan untuk non-Muslim mereka dapat diarahkan oleh perintis yang ketat melalui perempat. Dengan tujuan agar mereka diandalkan untuk lugas dalam melakukan pemanggilan kerja masing-masing. ${ }^{11}$

\section{SIMPULAN}

Kode etik panggilan adalah ikrar jabatan yang juga dipertegas oleh otoritas negara. Kode moral dan sumpah adalah jaminan yang harus dipegang teguh. Artinya, tidak ada kapasitas untuk menanggung setiap individu yang mengabaikannya. Hal ini sah, ada persyaratan untuk persetujuan brutal terhadap pelanggar ikrar dan ahli kode etik. Sejujurnya, dalam hal memenuhi unsur pidana atau kegiatan umum, pelanggar sumpah dan kode etik harus dibawa ke pengadilan. Kode moral dan sumpah jabatan harus benar-benar dilaksanakan. Pemanggilan apapun sebenarnya tidak memiliki perlawanan di bidang hukum. Penganiayaan terhadap panggilan dengan berlindung di balik kode etik ahli harus dimusnahkan. Kita harus menghentikan tindakan palsu dan manipulatif dari elit tertentu di mata publik. Hal ini signifikan dengan asumsi Indonesia perlu berubah menjadi bangsa dan negara yang mulia.

Ada beberapa alasan yang menyebabkan panggilan yang sah untuk mengabaikan kode etik ahlinya, antara lain:

1. Pengaruh Posisi, Seseorang mengabaikan kode etik ahlinya karena dia merasa terpaksa jika dia adalah bawahan dan diperlukan untuk menghormati dan tunduk pada setiap permintaan yang dibuat oleh atasannya.

2. Dampak komersialisasi, seseorang mengabaikan kode etik panggilannya karena melihat peningkatan kebutuhan yang tidak sebanding dengan gaji yang didapat. Hal ini mendorong seseorang untuk mendapatkan gaji yang lebih besar melalui jalur yang mudah, khususnya dengan mencari imbalan untuk administrasi dari perkumpulan yang dilayaninya.

3. Dampak Lemahnya Iman, Seseorang mengabaikan kode etik panggilannya karena tidak memiliki benteng kokoh dari pelajaran yang ketat. Sehingga menyebabkan terpikat dan terpikat oleh berbagai jenis material di sekitarnya.

\section{Daftar Pustaka \\ Buku}

Abdulkadir, Muhammad, Beberapa pengaruh dalam kode etik profesinya, Semarang, 2007.

Achmad, Ali, Menguak Teori Hukum (Legal Theory) dan Teori Peradilan (Judicialprudence) Termasuk Interpretasi Undang-Undang (Legisprudence), Jakarta : Kencana, 2009.

Friedman, M. Lawrence, diterjemahkan oleh Wishnu Basuki, Hukum Amerika Sebuah Pengantar, Jakarta : Tatanusa, 2001. Harahap, M.Yahya, Kode Etik sebagai pelaksana para profesionaletika profesi, Jakarta : 1998.

Magnis, Frans Suseno, Etika Politik Prinsip-Prinsip Dasar Kenegaraan Modern, Jakarta : Gramedia Pustaka Utama, (tanpa tahun).

Marmosudjono, Sukarton, Melihat Nilai Etika Dari Segi Keluhuran Hukum, Jakarta : 1998.

Orbith, Harian, Pengertian Etika dalam artian Luas, Jakarta, 2009.

Rasjidi, Lili dan Wyasa, I.B. Putra, Hukum Sebagai Suatu Sistem, Bandung : Mandar Maju, 2003.

Santoso, Agus, Hukum, Moral, Dan Keadilan. Jakarta : Kencana Prenada Media Group, 2014.

Soekanto, Soerjono, Jaksa. Jaksa Agung, Jakarta, 2009.

Supriadi, Etika \& Tanggung Jawab Profesi Hukum di Indonesia, Jakarta : Sinar Grafika, 2006.

Syahrani, H.Ridwan, Rangkuman Intisari Ilmu Hukum, Bandung : Citra Aditya Bakti, 1999.

Tedjosaputro, Liliana, Etika \& Tanggung Jawab Profesi Hukum Di Indonesia, Jakarta : Sinar Grafika, 2006.

\section{Peraturan Perundang-Undangan}

Undang-Undang Dasar Negara Republik Indonesia Tahun 1945

Undang-Undang Nomor 16 Tahun 2004 tentang Kejaksan Republik Indonesia

Peraturan Jaksa Agung Republik Indonesia nomor : PER-067/A/JA/07/2007 tentang Kode Etik Jaksa

\section{Internet}

https://journal.uniku.ac.id/index.php/logika/article/view/2182 